\title{
COMPROMISING LONG-TERM SUSTAINABILITY FOR SHORT-TERM PROFIT MAXIMI- ZATION: UNETHICAL BUSINESS PRACTICE
}

\author{
Mishelle DOORASAMY*, Kiran BALDAVALOO \\ University of Kwa-Zulu Natal, Westville, Durban South Africa \\ *e-mail: doorasamym@ukzn.ac.za
}

\begin{abstract}
The current environmental challenges caused by the dependence on nonrenewable energy, increased waste disposal, the toxic emissions created by operational activities, and also the scarce supply of water are so complex and important that it requires immediate attention. Strict environmental legislation, market pressures, and urgent need for sustainability have given businesses no option but to ensure that they do all that is possible to ensure that their business operations are sustainable. This paper addresses the underlying factors that determine the extent to which organizations adopt sustainable business practices and cleaner production techniques and technologies. It had been concluded that ethics is linked to sustainable business practices, because the objectives of both these concepts are to think about doing what's right for others and the world, including the environment. According to the organizational corporate compliance regulations, a company's commitment to ethical business and sustainable business practices should be detailed in their policy handbook and communicated to all employees within the company (Sustainability Report 2013/2014).
\end{abstract}

Keywords: sustainable development, business ethics, eco-efficiency, ISO14001, environmental performance, triple bottom line.

Introduction

Increased industrialized activities have led to the increased demand of scarce natural resources. This resulted in the depletion of our natural resources and irreversible damage to our environment. Both the global environment and the economy are in the midst of a period of great crisis. The question that many have raised is whether we can save our environment without destroying our economy? To some, this battle against global warming is seen as a "new great depression," while others perceive it as an opportunity to improve the financial performance while achieving their ultimate goal of the "triple bottom line" (Despeisse, Oales, and Ball, 2013, pp.31-41).

Waste and emissions is a sign of inefficiency in production. Waste is expensive because of the wasted material purchase value and not because of disposal fees (Jasch, 2009, p.2). Although most companies are ISO14001 certified because of the strict environmental regulations and market pressures, they are still not prepared to change production processes by moving toward cleaner production technologies. Many have adopted end-of-pipe technology as part of their sustainable practices. However end-of-pipe technologies only addresses the problems after the process, it does not address the cause of the problem. This leads to eventual accumulation of waste in landfill sites, which only shifts the focus of the real problem. In order for a company to remain sustainable and to achieve eco-efficiency in their production processes, there is an urgent need to adopt cleaner production techniques and technologies as part of the strategy toward sustainable development. As part of the requirement of ISO14001, it is critical that companies look at ways to achieve sustainable competitive advantage by improving their production process by implementing the use of clean technologies that reduce their raw material input, thereby resulting in lower amounts of waste or, at times, no waste at all. This will ultimately result in improved environmental performance and increased economic performance (Radonjic and Tominc, 2007, pp.1482-1493).

Eco-efficiency results in the company saving on their input material as well as having reduced costs for disposing of waste to landfill. Hence, there is likely to be financial and environmental benefits related to clean production technologies.

The question then raised is that if there are both environmental and economic benefits to cleaner technologies, why are companies reluctant to adopt such 
technologies as part of their business processes/operations?

The issue is that most companies are seeking to achieve short-term profitability instead of trying to find ways to ensure their long-term sustainability. Investing in environmental technology is costly with no real payback. Hence, most financial managers are reluctant to take the risk of high investment costs with no viable financial return.

Accountants and financial managers need to be made aware of the costs associated with unsustainable production processes that increase "environmental costs" (Doorasamy, 2014, p.8)

Managers are more focused on cost-reduction options using existing technology. Cleaner technologies are more efficient, as they prevent emissions at source. If a solution is adopted that does not reduce environmental impact by $100 \%$, then it is most likely to be an end-of-pipe treatment, which does not solve the problem at its source but shifts it to another environmental media, for example, dust filters that reduce emissions to the air by capturing components that are washed out by rainwater and when the filters are dry, they are disposed of on landfill. These approaches are costly and inefficient (Jasch, 2009, p.2). However, relatively newer technologies are unlikely to be replaced by cleaner technologies even if they can result in improved environmental and economic performance.

Therefore, when benchmarking environmental costs, life cycle of existing technology must be considered. In the short term, good housekeeping measures or minor improvements are preferred as part of cleaner production strategy. In the medium term, it makes sense that a company may change technology and get closer to state of the art of the industry. It is only in the long term that companies will consider changing state of the art to get closer to the ideal world of zero emissions where all inputs become part of the product. Theoretical standards are used to reflect this ideal world with no waste (Schaltegger, et al., 2012, pp.144-145).

\section{Significance of the study}

In many developing countries, an increase in industrial activity, electricity demand, and transportation results in emissions and poor air quality has become a major issue. Strategies to reduce dependence and use of energy from fossil fuels needs to be introduced (Stringer, 2010, pp.34-35).

Global trends and increased need for greater efficiency in supply chains because of higher energy and raw material prices are causing cleaner production to grow in relevance and importance. Inefficiency in production processes can affect both their profitability and competiveness.

It was concluded after a global evaluation of a joint cleaner production program by UNIDO (the United Nations Industrial Development Organization) and UNEP (the United Nations Environment Programme) that cleaner production strategy is still very appropriate for companies in both developed and developing countries. Most companies are using inefficient processes and technologies that are obsolete, which, therefore, consume more energy and resources than if they were using state-of-the-art processes. This ultimately results in higher production costs which in turn affects their profitability and competitiveness.

A direct consequence of these inefficiencies is rapid environmental degeneration, excessive amounts of pollution, and waste generation, which in turn is hazardous to human health and affects the quality of life (Schaltegger, et al., 2010, pp.10-11). A gap in knowledge have been identified on how to achieve the desired conceptual aims at operational level, even though there are numerous well-developed concepts for industrial sustainability and its contribution to manufacturing sustainability (Despeisse, Oales and Ball, 2013, pp.31-41).

Increased amounts of raw material used results in disposal of more by-products. Even though countries such as Japan produces half the amount of waste as compared to the United States, the amount of waste to landfill is increasing steadily. Industry and commerce are seen as the major contributors to the waste steam. One of the key strategies to be implemented along the "waste cycle" to reduce both the cost and environmental impact is to "reduce, reuse, and recycle" - in the exact order of preference.

Reduce and reuse has the greatest impact because not buying or buying less means less cost of raw materials purchased and processed and thus less by- 
products or waste to dispose of (Stringer, 2010, pp.29-31). This change or shift toward cleaner production processes may require investment in cleaner production technologies.

\section{$2 \quad$ Literature review}

\subsection{Business ethics}

Business ethics is based on the values of integrity, honesty, fairness, and transparency and provides a framework for policies and procedures within the organization. The code of business ethics is communicated to all employees to highlight the importance of compliance. Ethics motivates people to care about the world around them. Hence, its link to sustainable business practices is established. Ford's compliance to ethical standards are assessed regularly through legal audits that look the compliance to sustainable business practices (Sustainability Report 2013/2014). Corporate governance is the key to maintaining trust of investors and other stakeholders. The board of directors has emphasized that their key element to their commitment to transparency is to integrate sustainability reporting into organizational structures and business processes (Sustainability Report 2013/2014).

\subsection{Ethics within the sustainability framework}

Corporate sustainability report on Ford (2014) on ethical business practices, reported that latest research shows that "companies with strong accountability systems - board oversight, clear policies on human rights and environmental management, active stakeholder engagement and disclosure in many cases also have strong results on greenhouse gas emissions, use of renewable energy, strong work with suppliers, as well as driving sustainability into product and services." Sustainability provides a basis for decision-making such that the benefit of new technologies introduced outweighs the risk, benefiting both present and future generations. Ethical approach in sustainability supports sustainable development and provides a clearer understanding as to why sustainable development practices is the right thing to do. Ethics clarifies the role of values in decision-making and alternative course of action. The role of ethics and values in sustainable development needs to be transparent to help individuals and organizations choose their future business practices. Lonmin reported in their sustainability report (2012) that "Due to the nature and setting of our business, issues of transformation and sustainable development receive significant focus." It should be noted that almost all listed companies including KONE have included environment and sustainability and their commitment to minimizing environmental impact of the products and processes as part of their "Code of Conduct."

\subsection{Role and importance of EMA and CP in Sustainable Development}

Cleaner production $(\mathrm{CP})$ requires innovation. According to the $\mathrm{CP}$ philosophy that focuses on resources and resource flows, any reduction in material and energy used will result in fewer emissions. Within the context of $\mathrm{CP}$, resource efficiency is ecoefficiency, which is an instrument for sustainability analysis concentrating on the relationship between economic performance and resource use performance, an indication of how much environmental quality would offer in exchange in economic welfare. Relations between economy and environment are not self-evident at both micro and macro level (Thant and Charmondusit, 2010, p.427). Environmental management accounting (EMA) have developed to provide past-oriented information based on continuous recording system that provides information required for investment appraisal and financial planning. EMA has been challenged to focus on the broader concepts of $\mathrm{CP}$ and to provide adequate support information for $\mathrm{CP}$ decision-making in organizations (Schaltegger, et al., 2012, pp.11-15).

Audits into cleaner production assessments of production centers found that there are large savings potential and opportunities to be enjoyed but companies are not aware of it because there is no monitoring and data collection in place. As the old saying goes, "what you do not measure you cannot manage."

The environmental and sustainability accounting tool (EMA) gives companies the opportunity to collect, evaluate, and interpret the information needed to estimate their potential for cleaner production saving and to make decisions to choose the right $\mathrm{CP}$ options (Schaltegger, et al., 2010, pp.11-15). 
Companies implementing EMA systems needed to know exactly what they had to gain by using it and its role in CP. The concept of EMA was developed to show accountants how much they can save on environmental costs with particular emphasis on nonproduct output costs. This was facilitated by making use of material flow analysis, a tool of EMA. By identifying, assessing, and allocating environmental and material flow costs, EMA allows managements to identify opportunities for cost saving (Jasch, 2009, p.2). This process can assist in identifying inefficiencies in a production process and benchmark environmental costs to yield superior environmental and economic performance. Private environmental costs lead to higher prices and reduced competitiveness; therefore, there is clearly a trade-off between the firm's environmental costs and economic performance (Pons, Bikflavi, Llach, and Palcic, 2013, p.134). Empirical evidence on EMA and $\mathrm{CP}$ processes globally and in South Africa

A growing demand for raw materials by paper industries as a result of worldwide increase in the production and consumption of paper and paperboard. It is expected that paper consumption will increase to more than 490 million tons per year by 2020 (Mousavi, et al., 2013, pp.420-424). This has placed tremendous pressure on our environment and the demand of raw materials. Environmental degeneration and an increase in water and air pollution as well as global warming and ozone depletion are a direct result of increased industrial production and consumption of our natural resources (Aziz and Layeghi, 2008 , p.1). This has led to the introduction of sustainable development in business practices. Increasing energy prices and a greater demand for reduced carbon dioxide emissions have become a major challenge for the paper and pulp industry (Persson and Berntsson, 2010, pp.935-943).

In order to achieve sustainable competitive advantage, businesses need to adopt cleaner production processes. According to the UNEP, CP is defined as "the continuous application of an integrated preventative environmental strategy to processes, products and services to increase overall efficiency and reduce the risk to humans and the environment" (Fore and Mbohwu, 2010, pp.314-333).
Although a growing number of organizations in both manufacturing and service sectors demonstrated the potential to successfully reduce the operating costs as well as environmental impacts at the same time, the implementation of $\mathrm{CP}$ has been slow and lagging. Pilot studies by $\mathrm{CP}$ experts remain merely as niche examples and decision-makers in companies have failed to adopt this as a corporate strategy. It has been identified that there is clearly a shortcoming in the discrimination of information about the economic and environmental potential of CP (Schaltegger, 2010, pp.5-11).

A study conducted by Mendes (2012, p.1) showed that financial benefits by generating new reviews from the sale by products previously considered waste by adopting environmental management as a proposed model for clean technologies and ecoefficiency in a dairy industry.

Investigation/analysis/assessment is performed to understand the impact of ISO 14001 certification on environmental performance and the initiatives for the adoption of new and cleaner technologies within certified firms. This research was performed within Slovene metal and chemical manufacturing companies. It was found that 1S0 14001 created better conditions for the technology improvements in companies that were committed to the Integrated Pollution Prevention and Control (IPPC) directive. Companies in chemical and related industries adopted modified technologies to reduce their environmental impacts, while companies in metal industries used a combination of existing and new technologies after the 1SO 14001 certification. It had been concluded that better environmental performance is associated with greater productivity in firms that are ISO 14001 certified. (Radonjic' and Tominc, 2007, pp.1482-1493).

The United Nations development program as part of the Department of Sustainable Development reports EMA as an important management tool that is of benefit to both industry and government. UNEP have embarked on several activities to educate and encourage companies of the benefits of using EMA. Some of which was the following: being part of the expert working group on EMA which introduced the international guidance and also developing training course in EMA. 
Following these international developments, South African companies have considered environmental issues in their decision-making processes regarding products and processes. It has been suggested that EMA is a valuable tool for businesses to adopt while responding to environmental challenge and still focusing on the triple bottom line (Ambe, 2007, p.7). At the time of the study, there was an apparent lack of awareness and understanding of the significance of the environmental costs and its impact on the overall performance of the organization. What had been brought to the fore front was the potential savings to South African companies by implementing good environmental management by using EMA to accurately trace and identify environmental costs (Ambe, 2007, p.11-12). One of the reasons for companies questioning the necessity of implementing an EMA system, identified by Van (2012, p.3), was that results of an EMA system were only verifiable in the long run and not just environmental costs but also environmental benefits are important, as only investments with justifiable economical results would be initiated because of the competitive business environment.

A study conducted by Jonall (2008, p.2) by reviewing articles in academic journals revealed that corporate environmental costs to be much higher than the environmental costs disclosed by companies in their annual reports. There is greater potential for costs saving through strategy reconsiderations. EMA method identified material purchase value of nonproduct output costs to be the largest cost category. It was concluded that EMA can support decisionmaking in company toward improved environmental performance through structured costs assessments, more effective product mixes, strategies, and investments.

Schatlegger, et al.'s (2010, p.11-17) investigation into $\mathrm{CPs}$ has suggested that because $\mathrm{CP}$ requires innovations, there is a need for requirements of EMA to more detail from a given, standardized set of procedures to tools that are more flexible, indicatorbased approaches. CP sets a challenge for research in EMA to provide frameworks that needs to be couched in terms of their theoretical foundations that focus on drivers of change as well as incentives and barriers to change in the technological, organiza- tion, and accounting innovations context and their development. A test project undertaken by Schaltegger, et al. (2010, p.17-19) in four companies to assess their sustainable performance after a combine application of EMA, cleaner production assessment (CPA), and environmental management systems (EMS) generated positive outcomes.

It was found that EMA has made positive contribution to the enhancement of CPA/EMS projects by increasing awareness of the economic implications of the environmental impact of nonproduct output and costs and provided a systematic method of controlling these costs in the short, medium, and long term. EMA also helped to quantify monetary benefits of adopting alternator $\mathrm{CP}$ options. Two of the companies extended their scope of EMA to analyze other technological processes and in the process made important decisions regarding phasing out products and making new investments on the basis of the results of the EMA test project.

Research studies were conducted on clean technologies and environmental management on a small dairy industry in Brazil. This case study revealed that the proposed model of environmental management for clean technologies and eco-efficient generated positive results such as generation of additional revenue from the sale of by-products that were previously considered waste (Mendes, 2012, p.100-106). Beneficial use of paper mill by products without significant risks to the environment or human health has been identified during studies conducted by the National Council for Air and Stream Improvement, government agencies, universities, and individual paper companies. Coal ash, a by-product from paper mill boilers, can be used as a concrete additive. Some ashes are even used in soil stabilization or earthen construction application (Promoting Sustainable Use of Industrial Material 2013).

Analysis into steam generation system found that in addition to the technical standards of the system and standards of care, cleaner technologies shared other possible earning/gains: human gains less risk or danger of accident, environmental gains; less pollution and reduced waste generated at the end of the production process and financial gains; less spent on maintenance; and more efficient use of raw materials. It was concluded that there were positive re- 
sults in all departments in the environmental management system where the clean technology had been deployed. This confirms that actions generated in clean technology should no longer be seen only as costs, as they represent a number of benefits to industries assisted them in their endeavors in sustainable development and achieving their goals of the "triple bottom line" (Mendes, 2012, p.100-106).

\subsection{Research methodology}

This study involved both qualitative and qualitative research methods. Application of theories, concepts, and knowledge in the field of study and primary data from the survey questionnaire was also statistically analyzed and integrated to arrive at conclusions and recommendations.

The sample population involved only top- and middle-level management of the organizations used in the study, because the information needed were strategic and tactical in nature. A total of 50 questionnaires were distributed and 45 questionnaires were returned. Response rate of $90 \%$ is sufficient to ensure that the study was reliable. The data collected from the responses were analyzed with SPSS version 22.0. The data that were collected from the questionnaire were presented using descriptive statistics in the form of graphs, cross tabulations, and other figures. Inferential techniques used to analyze the quantitative data included the use of correlations and chi-square test values, which were interpreted using the p-values (Doorasamy, 2014, p.156).

The overall reliability score of each section exceeds the recommended value of 0.70 . This indicates a high (overall) degree of acceptable, consistent scoring for the research.

\section{$3 \quad$ Anaysis of data and findings}

\subsection{Corporate environmental strategy of the organization}

This section deals with management's perception of the extent to which environmental issues are integrated into the organization's corporate strategies.

The uncertainty to this question is evidenced by the large number of respondents indicating a neutral view on the last two statements, with $31.43 \%$ for statement three and $45.71 \%$ for statement four. According to Schaltegger, et al. (2010, p.24-25) management commitment has a substantial influence ment's awareness of the responsibility to the environment during strategic decision-making is important to reflect this commitment inside and outside the organization (Fig. 1).

Lack of clear environmental goals is one of the obstacles to environmental performance measurement (Mohr-Swart, 2008, p.174).

Table 1. Test Statistics

\begin{tabular}{|c|c|c|c|c|}
\hline & $\begin{array}{l}\text { Integrated environmen- } \\
\text { tal issues are incorpo- } \\
\text { rated into the compa- } \\
\text { ny's strategic planning } \\
\text { process }\end{array}$ & $\begin{array}{l}\text { Reducing the environmental } \\
\text { impact of products and pro- } \\
\text { cesses forms part of the total } \\
\text { quality management (TQM) } \\
\text { policy }\end{array}$ & $\begin{array}{l}\text { Environmental ob- } \\
\text { jectives are linked } \\
\text { with the company's } \\
\text { corporate goals }\end{array}$ & $\begin{array}{l}\text { During the development } \\
\text { of new products, envi- } \\
\text { ronmental issues are al- } \\
\text { ways considered }\end{array}$ \\
\hline Chi-square & $13.943^{\mathrm{a}}$ & $18.057^{\mathrm{a}}$ & $.743^{\mathrm{a}}$ & $13.114^{\mathrm{b}}$ \\
\hline $\mathrm{df}$ & 2 & 2 & 2 & 3 \\
\hline $\begin{array}{c}\text { Asymp. } \\
\text { Sig. }\end{array}$ & .001 & .000 & .690 & .004 \\
\hline \multicolumn{5}{|c|}{$\begin{array}{l}\text { Asymp. Sig. is an abbreviation for asymptotic significance, which means that he significance is ridiculoiusly close to } 0 \\
\text { because you're way out in the tail of the test! }\end{array}$} \\
\hline
\end{tabular}


To determine whether the differences were significant, chi-square tests were done by variable (statement). The null hypothesis tested the claim that there were no differences in the scoring options per statement. The results are shown in Table 1.
As all but one of the significance values (p-values) are less than 0.05 (the level of significance), it implies that the distributions were not even. That is, the differences between the levels of agreement were significant. Similar scoring patterns were observed for statement three $(p=0.690)$.

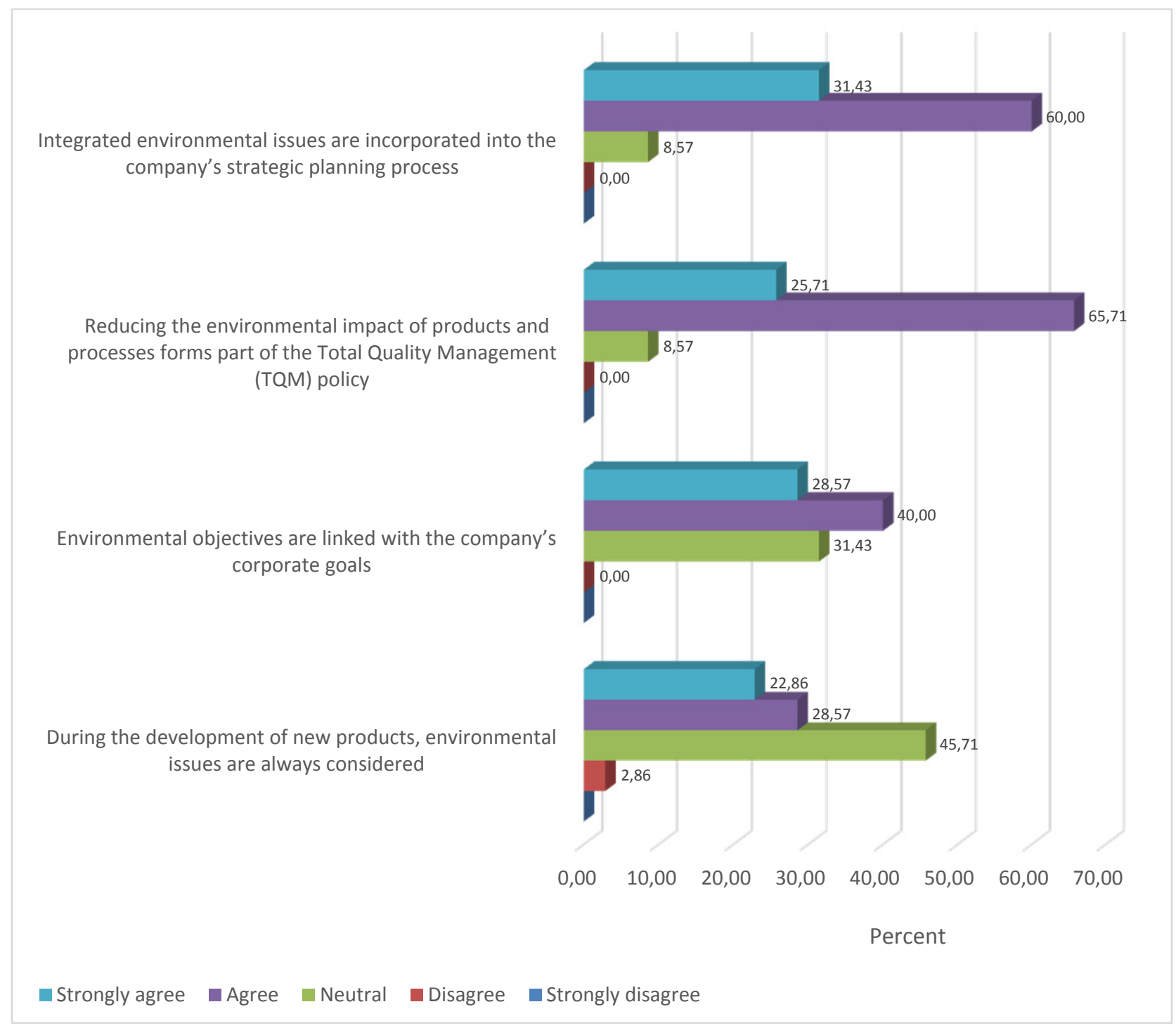

Figure 1. Corporate environmental strategy

The average level of importance for this section was $75.71 \%$. The first two statements average $91.43 \%$ with the last statement lowering the overall average, with only half of the respondents agreeing $(51.43 \%)$. Even though the level of agreement is reasonably high, the statements relating to environmental issues are always considered during new product develop- ment and objectives being linked with the company's corporate goals, scores lower than the rest.

Differences in the level of agreement clearly indicate that managers have limited knowledge on the organization's corporate environmental strategy, especially in areas concerning environmental objectives and new product development (Doorasamy, 2014, p.158). 


\subsection{Reasons for the promotion of clean production by industries}

This section investigates the manager's perception of factors that promote the adoption of $\mathrm{CP}$ in industries.
Table 2 is the average rank score of the factors, ranked from the highest to the lowest levels of importance.

Table 2. Promotion of cleaner production

\begin{tabular}{|l|c|}
\hline & Mean \\
\hline The fear for business sustainability in the future and its uncertainties & 4.54 \\
\hline The market pressures for cleaner products and processes & 3.97 \\
\hline Strict legislation and environmental crime law & 3.80 \\
\hline The greater business managers' awareness and commitments to the environmental aspects & 2.94 \\
\hline Many emotional aspects connected with environment and the company's productive activity & 2.43 \\
\hline
\end{tabular}

The most important factor is identified as being uncertainty regarding business sustainability.

The results indicate that external factors have a more significant impact on whether or not an organization will adopt cleaner production than internal factors. The first three factors are external while the last two factors, rated as less important, are internal factors (Doorasamy, 2014, p.160).

The contingency theory could be used to explain why managers have identified uncertainty regarding business sustainability as the most important factor. It can be inferred from Qian, Burritt and Manroe (2011, pp.93-128) that there is no single best approach to sustainability because the external business environment is characterized by uncertainty.

They concur that the optimal course of action will depend on factors such as company's environment, technology, and culture. According to the Institute of Environmental Engineering and the UNEP, internal barriers to $\mathrm{CP}$ implementation within a company are low commitment from management, lack of environmental awareness, poor communication links, and financial obstacles. Therefore, the last two constructs have been rated as less important.

Fore and Mbohwa (2010, pp.314-333) identified barriers to cleaner technology adoption as less stringent government regulations and policies, resource unavailability, and lack of financial initiative.

This supports the respondents' view to a certain extent that external factors, such as market pressures, strict legislation and, most importantly, uncertainty of the businesses future sustainability, are the driving forces of CP implementation.

\subsection{Perspectives of environmental management accounting}

This section is concerned with manager's perception of EMA practices within the organization (Fig. 2).

This finding suggests that most of the environmental management accounting practices are not being implemented within the organization except for environmental impact audits. As the organization is ISO 14001 accredited, environmental impact audits are mandatory.

The company uses a traditional cost accounting system that is inadequate in incorporating environmental information into general management accounting information. Findings in question two above related to environmental activities also suggest that EMA system is not being implemented by the company.

According to Benette, Schaltegger, and Zvezdov (2013), EMA is a tool that tracks and traces environment-related costs that are generally hidden under overheads to assist managers in decision-making. Recent developments in EMA emphasize the greater need for accounting information when making decisions regarding environmental projects (Qian and Burritt, 2008, p.244). 


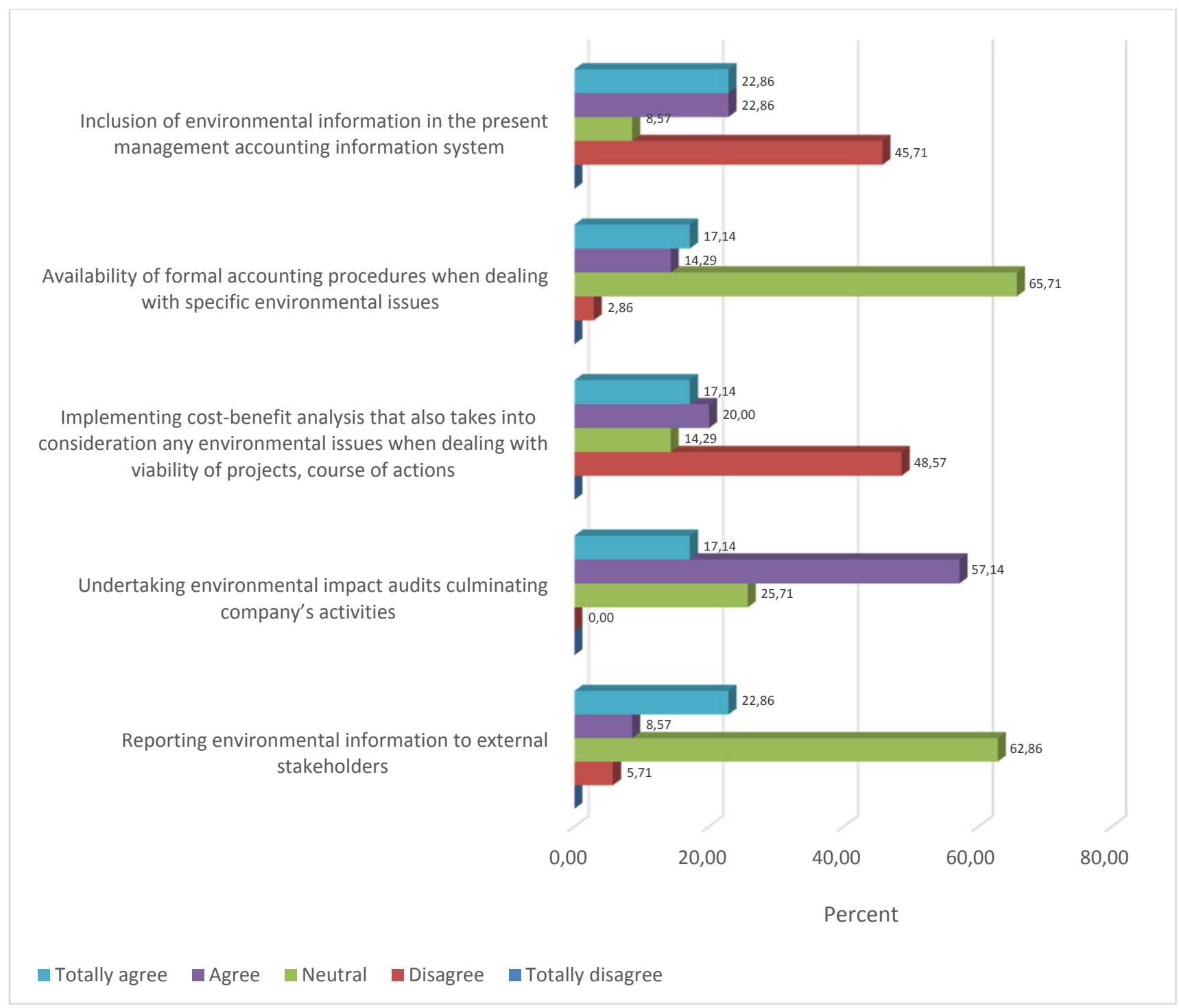

Figure 2. Perspectives of Environmental Management Accounting

Previous research by Jasch and Schnitzer (2002, p.6) showed a lack of communication between the environmental manager and cost accountant in companies. The environmental manager has limited access to actual cost accounting documents, and although the cost controller has most of the information, they lack the ability to separate the environmental part without proper guidance. EMA is a combined approach to bridge this communication gap and provide for the transition of data from cost accounting and financial accounting to reduce the environmental impact by increasing material efficiency.

Hence, it was implied that in order to enable the sharing of environmental information needed to stimulate management accounting practices, for- mal and informal interactions between different functions are required.

Environmental reporting and environmental audit are based on the "stakeholder theory" that implies that a company needs to conduct their business operations in a way that is socially acceptable by the community. It can be inferred from Godschalk (2008, p.250) that some firms place greater emphasis on stakeholders, as they believe that this is critical to the firms' success and to ensure future sustainability. This could explain the reason for the high level of agreement for statement four.

Table 3 indicates the chi-square results for differences in the scoring patterns. 
Table 3. Test Statistics

\begin{tabular}{|c|c|c|c|c|c|}
\hline & $\begin{array}{l}\text { Inclusion } \\
\text { of environmental } \\
\text { information } \\
\text { in the present } \\
\text { management } \\
\text { accounting } \\
\text { information } \\
\text { system }\end{array}$ & $\begin{array}{l}\text { Availability of formal } \\
\text { accounting procedures } \\
\text { when dealing with } \\
\text { specific environmental } \\
\text { issues }\end{array}$ & $\begin{array}{l}\text { Implementing cost- } \\
\text { benefit analysis that } \\
\text { also takes into } \\
\text { consideration any } \\
\text { environmental } \\
\text { issues when dealing } \\
\text { with viability } \\
\text { of projects, course of } \\
\text { actions }\end{array}$ & $\begin{array}{l}\text { Undertaking } \\
\text { environmental } \\
\text { impact audits } \\
\text { culminating } \\
\text { company's } \\
\text { activities }\end{array}$ & $\begin{array}{l}\text { Reporting } \\
\text { environmental } \\
\text { information } \\
\text { to external stake- } \\
\text { holders }\end{array}$ \\
\hline $\begin{array}{l}\text { Chi- } \\
\text { Square }\end{array}$ & $9.914^{\mathrm{a}}$ & $32.543^{\mathrm{a}}$ & $10.600^{\mathrm{a}}$ & $9.314^{b}$ & $29.114^{\mathrm{a}}$ \\
\hline $\mathrm{df}$ & 3 & 3 & 3 & 2 & 3 \\
\hline $\begin{array}{c}\text { Asymp. } \\
\text { sig. }\end{array}$ & 0.019 & 0.000 & 0.014 & 0.009 & 0.000 \\
\hline \multicolumn{6}{|c|}{$\begin{array}{l}\text { a } 0 \text { cells }(0.0 \%) \text { have expected frequencies less than } 5 \text {. The minimum expected cell frequency is } 8.8 \\
\text { b } 0 \text { cells }(0.0 \%) \text { have expected frequencies less than } 5 \text {. The minimum expected cell frequency is } 11.7 \text { (Doorasamy, } \\
2014: 162)\end{array}$} \\
\hline
\end{tabular}

As all of the values are less than the levels of significance $(p<0.05)$, it implies that the differences observed in the scoring per option per statement was significant.

The average level of agreement is $44.00 \%$.

The level of agreement is fairly consistent except for statement four, which relates to the undertaking environmental impact audits culminating company's activities $(74.29 \%)$.

Two of the statements show high levels of neutrality, while the remaining statements indicate higher levels of disagreement.

This finding suggests that most of the environmental management accounting practices are not being implemented within the organization except for environmental impact audits. As the organization is ISO 14001 accredited, environmental impact audits are mandatory. The company uses a traditional cost accounting system that is inadequate in incorporating environmental information into general management accounting information.

\subsection{Barriers to adoption of cleaner technologies}

This section deals with factors that are considered barriers to the adoption of cleaner technologies (Table 4, Fig. 3).
The average level of agreement is $54.57 \%$.

Some statements show high levels of agreement and others do not, for example higher initial capital cost and difficulty to access information on CT scores has higher levels of agreement as compared to "higher priorities to production equipment" and "the absence of incentives on economic policies," which has extremely low levels of agreement.

Higher initial capital cost had the highest level of agreement of $85.72 \%$, followed by relaxed regulation and law enforcement and poor financial performance of cleaner technologies with agreement levels of $80 \%$ and $74.28 \%$, respectively. Interestingly, limited in-plant expertise and additional infrastructure requirements had the same level of agreement of $68.57 \%$.

Similarly, the absence of incentives on economic policies and higher priorities to production expansion had the same level of agreement of $25.72 \%$. Response relating to the last two statements: concern about competitiveness and management resistance to change revealed higher levels of disagreement of $54.28 \%$ and $60 \%$, respectively (Doorasamy, 2014, p.163). 
Table 4. Barriers to cleaner technology

\begin{tabular}{|l|c|c|c|c|c|}
\hline \multicolumn{1}{|c|}{ Question 7 } & $\begin{array}{c}\text { Totally } \\
\text { disagree }\end{array}$ & Disagree & Neutral & Agree & $\begin{array}{c}\text { Totally } \\
\text { agree }\end{array}$ \\
\hline Relaxed regulation and law enforcement & 0.00 & 2.86 & 17.14 & 68.57 & 11.43 \\
\hline Absence of incentives on economic policies & 0.00 & 14.29 & 60.00 & 14.29 & 11.43 \\
\hline Higher initial capital cost & 0.00 & 2.86 & 11.43 & 34.29 & 51.43 \\
\hline Poor financial performance of cleaner technologies & 0.00 & 2.86 & 22.86 & 65.71 & 8.57 \\
\hline Limited in-plant expertise & 0.00 & 2.86 & 28.57 & 60.00 & 8.57 \\
\hline Difficulty to access information on CT & 0.00 & 2.86 & 25.71 & 71.43 & 0.00 \\
\hline Additional infrastructure requirements & 0.00 & 8.57 & 22.86 & 60.00 & 8.57 \\
\hline Higher priorities to production expansion & 11.43 & 42.86 & 20.00 & 14.29 & 11.43 \\
\hline Concern about competitiveness & 8.57 & 45.71 & 22.86 & 20.00 & 2.86 \\
\hline Management resistance to change & 11.43 & 48.57 & 17.14 & 17.14 & 5.71 \\
\hline
\end{tabular}

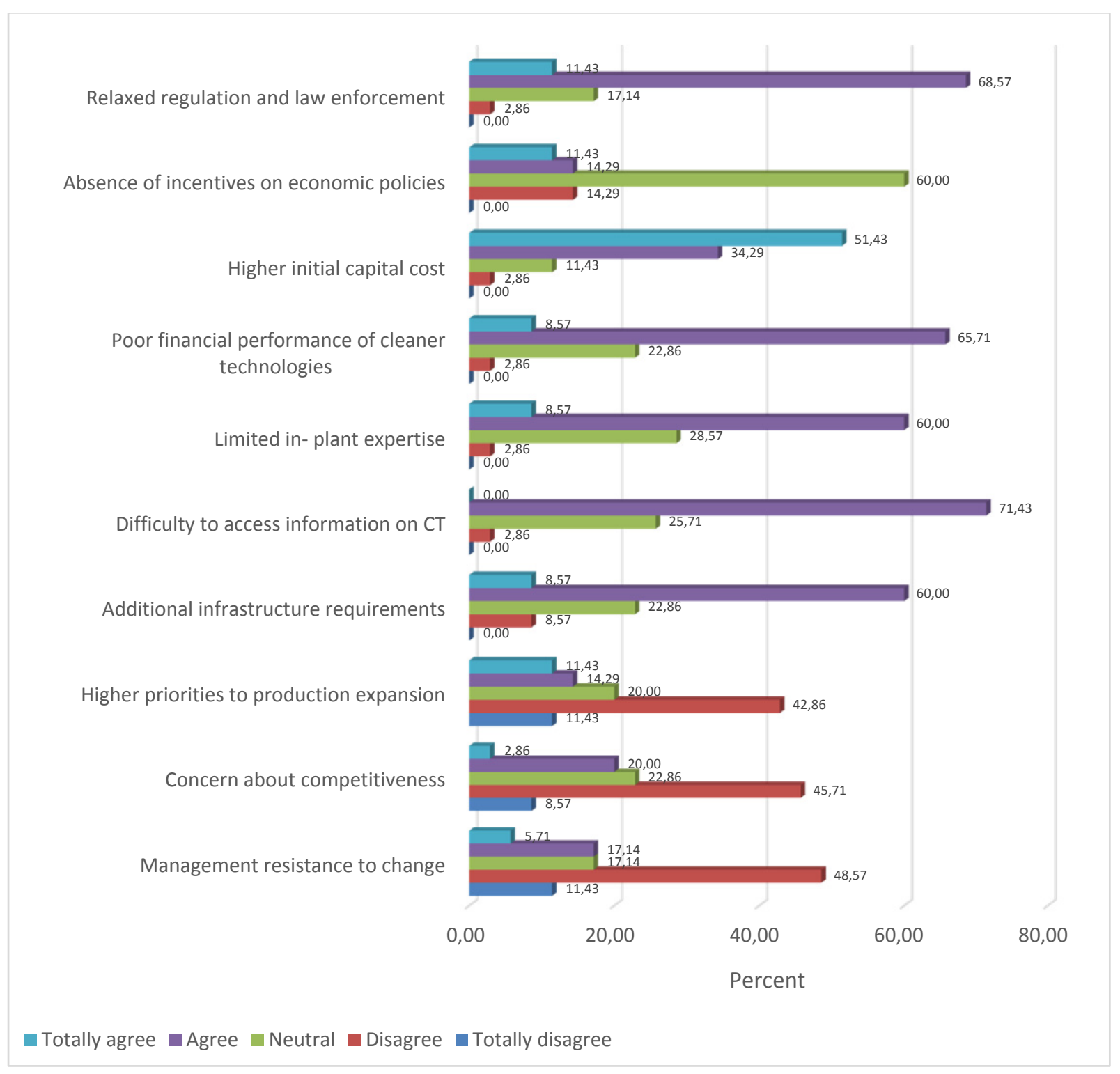

Figure 3. Barriers to $\mathrm{CP}$ implementation 
Research studies had identified insufficient investment capital, lack of domestic suppliers, and unsatisfactory government policies as key barriers to the adoption of cleaner technologies (Nguyen, HaDuong, Tran, Shrestha and Nadaud, 2010, p.1).

They also claimed that technological barriers such as the lack of infrastructure and poor technical knowledge and capabilities affected cleaner technology adoption in developing countries. Fore and Mbohwa (2010, pp.314-333) identified lack of financial initiative as barriers to cleaner technology adoption in Sri Lanka; resource unavailability and less stringent government regulations and policies as being some of the major issues.

\subsection{Correlations}

Bivariate correlation was also performed on the (ordinal) data. The results indicate the following patterns.

Positive values indicate a directly proportional relationship between the variables, and a negative value indicates an inverse relationship (Doorasamy, 2014, pp.182).

For example, the correlation value for Business factors between "Integrated environmental issues are incorporated into the company's strategic planning process" and "Environmental objectives are linked with the company's corporate goals" is 0.721 .

This is a directly related proportionality. Respondents agree that the more integrated environmental issues are incorporated into the company's strategic planning processes, the more likely the environmental objectives are linked with the company's corporate goals, and vice versa.

Respondents also agree that allocation of environment-related costs to production processes and classification of environment-related cost results in improvements to environment-related cost management (correlation of 0.880 and 0.978 , respectively).

Further analysis shows that assessments of environmental impact issues during capital investment decisions demonstrate greater commitment and awareness of environmental issues by the business managers (positive correlation of 0.748 ).
In addition, findings reveal that old technologies used in production indicate management's resistance to change (positive correlation 0.701 ).

Negative values as identified in the correlation results imply an inverse relationship. That is, the variables have an opposite effect on each other. Analysis on negative coefficients for certain variables was interpreted as follows.

The coefficient between "The fear for business sustainability in the future and its uncertainties" and "Classification of environment-related costs" is -0.664 .

This finding indicates that the greater the environmental business costs, the less sustainable the businesses may become, and vice versa.

Interestingly, a negative correlation exists between inclusion of environmental information in the present management accounting information system and input and raw material waste. This means that input and raw material waste decreases when environmental issues are incorporated into the company's management accounting system $(-0.656)$. This trend indicates an inverse relation between environmental management activities practiced and input and raw material waste generated. Hence, by incorporating environmental management activities into daily business operations, input and raw material waste generated can be reduced and manufacturing can be improved.

\section{$4 \quad$ Recommendations}

This implies that environmental issues need to be incorporated into the long-term goals of the organization, which requires a strategic work plan to be implemented and budgeted for.

There is a need to increase pressure on business managers to include environmental objectives in the operational planning, which seems to be currently lacking in the company. Operational activities need to be aligned to strategic objectives.

The effectiveness of the company's current system from an environmental point of view is questionable because it is difficult to assess the extent to which environmental objectives are fulfilled. 
Environmental objectives in terms of targets and improvement measures are not clearly connected to the strategic objectives and absent from general management system.

Research suggests that even though a company may have well-formulated objectives and suitable indicators measuring progress toward achieving objectives, actual improvements are unlikely to be achieved unless employees are committed and motivated to work toward improving environmental performance (Lundberg, 2009). Hence, the link between ethics and sustainable business practices needs to be reinforced among employees and management.

Managers in the company are unaware of the company's progress and performance to environmental objectives because of the lack of feedback and unclear structures.

It is, therefore, suggested that EMA can be used as a tool to assess and value this "environmental costs" to the company so that they can realize what amount they would be saving in the long run by adopting cleaner production techniques and technology.

\section{$5 \quad$ References}

[1] Ambe, M.C., 2007. Environmental Management Accounting in South Africa. Status, challenges and implementation framework. D. Tech. Tshwane University of Technology.

[2] Azizi, P.G.M., Layeghi, M., 2008. A Strategic Model for Cleaner Production Implementation In Paper Making Mill.

[3] Bennett, M., Schaltegger, S., Zvezdov, D., 2011. Environmental management accounting. Review of Management Accounting Research, pp.53-84.

[4] Despeisse, M., Oates, R. M., Ball, D.P., 2013. Sustainable manufacturing tactics and crossfunctional factory modelling. Journal of Cleaner Production, 42:31-41, [online] Available at: http://www.sciencedirect.com/science/article/ [Accessed 21 June 2015].

[5] Doorasamy, M., 2014. Using EMA to identify the benefits of Cleaner Production at a paper manufacturing company in Kwa-Zulu Natal: A case study. Master's thesis. Durban University of Technology.
[6] Ethical business practices. KONE Corporation, 2014 [online] Available at: http://dutlib.dut.ac.za

[7] Fore, S., Mbohwa, G.T., 2010. Cleaner production for environmental conscious manufacturing in the foundry industry. Journal of Engineering Design Technology 8(3):314-333 [online] Available at:

http://www.emeraldinsight.com/doi/abs/10.1108/ 17260531011086180 [Accessed 6 Aprile 2016].

[8] Godschalk, S., 2008. Does Corporate Environmental Accounting Make Business Sense. Ecoefficiency in Industry and Science. 24:249-265. [online] Available at:

http://www.academia.edu/10384051/does_copor ate_environmental_accounting_make_business sense [Accessed 9 November 2015].

[9] Jasch, C., 2009. Environmental and Material Flow Cost Accounting Principles and Procedures (Eco-Efficiency in Industry and Science Series, vol. 25). Journal of Industrial Ecology. Springer science and Business Media: Berlin (2, pp.832834).

[10] Jasch, C., Schnitzer, H., 2002. Environmental Management Accounting. How to profit from environmental protection. EMA- environmental management accounting pilot testing.

[11] Jonall, P., 2008. Environmental Management Accounting (EMA), Management Accounting including Environmental Management: 2.

[12] Lundberg, K., 2009. Monitoring as an instrument for improving environmental performance in public authorities. Doctoral thesis. KTH - Environmental Management and Assessment Research Group. Department of Land and Water Resources Engineering. Royal Institute of Technology (KTH), Sweden.

[13] Mendes, L., 2012. Clean Technologies and Environmental Management: A Study on a Small Diary Industry in Brazil. Resources and Environment, 2(3):100-106, [online] Available at: http://journal.sapub.org/re [Accessed 5 July 2015].

[14] Mohr-Swart, M., 2008. An Environmental Management Accounting Model for the South African Mining Industry. Doctor of Technology in the Department of Environmental, Water and Earth Sciences, Tshwane University of Technology. 
[15] Mousavi, M.M.S., Hosselini, Z.S., Resalati, H., Mahdavi, S., Garmaroody, E.R., 2013. Papermaking potential of rapeseed straw, a new agricultural-based fibre source. Journal of Cleaner Production 52:420-424.

[16] Nguyen, N.T., Ha-Duong, M., Tran, T.C., Shrestna, R.M., Nadaud, F., 2010. Barriers to the adoption of renewable and energy-efficient technologies in the Vietnamese power sector. GMSARN International Journal, [online], 4(2): 89-104. [Accessed 23 January 2014].

[17] Persson, J. Berntsson, T., 2010. Influence of short-term variations on energy-saving opportunities in a pulp mill. Journal of Cleaner Production, 18:9335-943.

[18] Pons, M., Bikfalvi, A., Llach, J., and Palcic, I., 2013. Exploring the impact of energy efficiency technologies on manufacturing firm performance. Journal of Cleaner Production, 52:134144, [online] Available at:

http://elsevier.com/locate/jclepro [Accessed 1 June 2015].

[19] Qian, W., Burritt, R., 2008. Contingency Perspectives on Environmental Accounting: An Exploratory Study in Local Government, the 1st International Conference of the Global Accounting and Organisational Change, July 9-11, Melbourne.

[20] Qian, W., Burritt, R., Monroe, G., 2011. Environmental management accounting in local government: A case of waste management. Accounting, Auditing \& Accountability Journal, 24 (1): 93-128.
[21] Radonjič, G. and Tominc, P., 2007. The role of environmental management system on introduction of new technologies in the metal and chemical/paper/plastics industries. Journal of Cleaner Production, 15 (15): 1482-1493.

[22] Schaltegger, S., Bennett, M., Burritt, R.L., Jasch, C., 2010. Eco-efficiency in industry and science. Environmental Management Accounting for Cleaner Production. $5^{\text {th }}$ edition. Springer Science and Business Media. UK.

[23] Schaltegger, S., Viere, T. Zvezdov, D. 2012. Tapping environmental accounting potentials of beer brewing: Information needs for successful cleaner production. Journal of Cleaner Production, 29-30:1-10.

[24] Stringer, L., 2010. The Green Workplace- Sustainable strategies that benefit employees, the environment, and the bottom line. Paperback edition. New York: Palgrave Macmillan.

[25] Sustainability Report 2013/2014 - Ford. (2014). Ethical Business Practices, [online] Available at: www.corporate.ford.com [Accessed 21 June 2015]

[26] Thant, M.M., Charmondusit, K., 2010. Ecoefficiency assessment of pulp and paper industry in Myanman. Clean Technology Environmental Policy, 12:427-439.

[27] V'an , H., 2012. Environmental benefits and its statement in Environmental Management Accounting. Ph.D. University of Szeged. 